\title{
Using Twitter's "Hashtag" in Television Series to Create A Social Capital: Season Final Episodes of Turkish Television Series
}

\author{
Research Assistant Enes ABANOZ \\ Ondokuz Mayıs University, Communication Faculty, Journalism Department \\ enes.abanoz@omu.edu.tr
}

\begin{abstract}
Nowadays, due to the popularity of different social network sites, many companies and institutions try to reach members of these sites for various reasons. Social network sites, provide social capital to its followers by utilizing the flow of information provided by the connection of its members. Social capital consists of information and facilities that are obtained from individuals within these social networks. In this study, we will evaluate the final episodes of five distinct television series that utilizes Twitter's hashtag function in order to create social capital.
\end{abstract}

Keywords: Social Capital, Twitter, hashtag, television series, social networks.

Özet

Sosyal paylaşım ă̆ların giderek popülerliğini artırdı̆̆ı bu günlerde, birçok firma ve kurum farklı amaçlar çerçevesinde bu ă̆larda bulunan bireylere ulaşmaya çalışmaktadır. Sosyal paylaşım ă̆lar, sahip oldukları bireyler ve bu bireyler arasındaki bilgi akışı ile kullanıcılarına sosyal sermaye să̆lamaktadırlar. Sosyal sermaye, bireylerin sosyal ă̆lar ile elde ettiği bilgi ve olanaklardır. Bu çalışma kapsamında, twitter'da -sosyal paylaşım ă̆ında- hashtag uygulaması kullanan televizyon dizilerinin sezon finalleri sosyal sermaye kapsamında değerlendirilmiştir. Dizilerin bu uygulamalar ile sosyal paylaşım ă̆ında hashtag ile etkileşime giren bir grup oluşturduğu belirlenmiştir.

Anahtar Kelimler: Sosyal Sermaye, Twitter, hashtag, televizyon dizisi, sosyal paylaşım ă̆ları. 


\section{Introduction}

Like face-to-face communication, computer-mediated communication has the capacity of enabling high interactivity (Rafaeli, 1997). Specifically, this notion can be observed in various social network sites. Social network sites allow individuals to maintain, create and augment connections with other people of similar interests. This structure proves mutually beneficial in both person-to-person and person-to-institution communications.

Social network sites facilitate communicative action by mobilizing elements that provide common sense by "socially integrating consensus about norms and values instilled through cultural tradition and socialization." (Habermas,1984) This bonding process of individuals via communicative action produces social capital.

\section{Social Capital}

According to social capital theory, there are some abilities and values rooted in social networks and relationships that produce advantages for people to use (Sum\&al, 2008). Many scholars such as Pierre Bourdieu, James S. Coleman, Ronald S. Burt and Robert D. Putman approach the concept of social capital. Bourdieu (1986) states social capital is "the aggregate of the actual or potential resources which are linked to possession of a durable network of more or less institutionalized relationships of mutual acquaintance and recognition - or in other words, to membership in a group - which provides each of its members with the backing of the collectivity-owned capital, a credential which entitles them to credit, in the various senses of the word" (p.248). According to Bourdiue, social capital is a resource that an individual can benefit from by being able to access a specific group along with its members; who can also be utilized as a resource through their individual connections. Burt (1992) defines social capital as "contacts through which someone receives opportunities to use your financial and human capital" (p.9), Putman (2000) referred to social capital as "connections among individuals - social networks and the norms of reciprocity and trustworthiness that arise from them," (p.19). Coleman (1990) further advanced this concept to explain how relations among persons can facilitate the achievement of goals. Social capital provides an efficient way to get otherwise costly information and facilitates action. Francis Fukuyama underlines two important points of social capital, primarily that "it is not a subset of human capital because it is a property of groups and not individuals" (Fukuyama, 1997). In order for social capital to have any meaning at all it needs a group structure of at least two people. The second point Fukuyama makes is that "social capital is not necessarily a good thing, with regard to either politics or economics," since morally evil entities have a sense of social capital within themselves, such as the Mafia or Ku Klux Klan. 
Since the introduction of the internet, informational- and emotional support have been exchanged not only in offline communities but also in online communities (Lee, 2006). Due to their networked structures, online communities are able to provide information as well as emotional support to their members, who could not otherwise receive them from offline social networks. Online communities help build social capital by allowing their users to keep their existent connections while they make new ones.

\section{Twitter and Using "Hashtag" Function}

Twitter is an online social network used by millions of people around the world. It socially connects an individual either to another person or a group. Twitter users can update their statuses with a message of at-most 140 characters, also known as a "tweet". In Twitter, a user can follow other users; his/her followers can read his/her tweets. A user who is being followed by another user need not necessarily reciprocate by following them back, which renders the links of the network as directed (Sakaki, 2010). Common practice of responding to a tweet has evolved into well-defined markup culture: RT stands for retweet, '@' followed by a user identifier address the user, and '\#' followed by a word represents a hashtag (Kwak, 2010). Using a hashtag is an easy and effective way to reach many people. Members can create circulation among other users by sending out "tweets" with corresponding hashtags. Another important characteristic of Twitter is that its realtime nature. This allows users to use it in a real time event such as conferences, press releases, live coverages and television series.

Many academic studies that are related social network sites show that there is a relation between using social network sites and social capital. DeAndrea et al. (2011) found associations between Facebook usage and various forms of social capital. The study shows that students using Facebook to communicate with fellow students can acquire information as a form of social capital that can be used later in their college education. Ellison et al. (2007) also found a relationship between using Facebook and social capital among college students: the students use Facebook primarily to maintain existing offline relationships or to solidify what would otherwise be ephemeral, temporary acquaintanceships.

\section{Method}

On this study, season finales of five television series which use hashtags during air time were selected according to their ratings. All season final episodes were aired in different weeks of June 2012, therefore, in order to determine the ratings of the series, the last week of May was chosen. Specific hashtags were examined for 24 hours from the time they first aired on their related episodes.

According to social capital theory; participants need to get into the act to create information that could be used as a social capital. In Twitter, creating a tweet that utilizes a hashtag is more difficult than using retweet. Hence, on this study we prefer to use oeiginal tweets rather than retweets to measure social capital points. Twitter allows its users to create tweets that are limited to 140 characters; it requires a great amount of effort to utilize all 140 characters while the tweet still retains its meaning. Thus, we will use this formula to find social capital point: 


\section{Soctal Capttal Potnt $=\frac{\text { Tweet Character Count }+140}{\text { Total Tweet Count }}$}

\section{Findings}

Even though there was a small drop of shares on two of the five series we examine (Seksenler and Yalan Dunya), we can observe that season finales in general have an increased share than usual, as well as "TOP AB 100" rankings. Seksenler declined from rank 2 with 18,3\% viewing shares down to rank 3 with 15,5\%, while Yalan Dünya lost 2,7 of its shares and took the second place in 'TOP AB 100' list. However, the increase of the shares and rankings of other series -especially in Bir Zamanlar Osmal1-Kiyam and Suskunlar- proves that the decreased shares and rankings of Seksenler and Yalan Dunya is indeed miniscule; season finales gained more attention than regular episodes from audiences.

Table 1- Television Series Ratings, 21 - 25 May 2012

\begin{tabular}{lcccc}
\hline Name of Series & Channel & Average Minute Rating & Share & AB Ranking \\
\hline $\begin{array}{l}\text { Bir Zamanlar } \\
\text { Osmanlı-Kıyam }\end{array}$ & TRT 1 & 2,13 & 5,53 & 17 \\
Seksenler & TRT 1 & 6,67 & 18,3 & 2 \\
Kuzey Güney & Kanal D & 6,85 & 17,5 & 2 \\
Suskunlar & Show Tv & 3,78 & 9,53 & 8 \\
Yalan Dünya & Kanal D & 9,25 & 23,9 & 1 \\
\hline
\end{tabular}

Source: SBT Rating

Table 2- Television Series Season Final Episode Ratings, 04 - 29 June 2012

\begin{tabular}{|c|c|c|c|c|}
\hline Name of Series & Channel & Average Minute Rating & Share & \\
\hline \multicolumn{5}{|l|}{ Bir Zamanlar } \\
\hline Osmanlı-Kıyam & TRT 1 & 3,58 & 10,7 & 6 \\
\hline Seksenler & TRT 1 & 5,57 & 15,5 & 3 \\
\hline Kuzey Güney & Kanal D & 6,62 & 22,4 & 1 \\
\hline Suskunlar & Show Tv & 6,16 & 18,3 & 3 \\
\hline Yalan Dünya & Kanal D & 5,83 & 21,2 & 2 \\
\hline
\end{tabular}

Source: SBT Rating 
Creating an original tweet needs much more interaction and effort than to simply retweet: a user should consider tweets, which have been sent from other users that are related to the subject in order to develop a meaningful interactive communication. Seksenler, got the highest circulation rate with $78 \%$ tweets and $22 \%$ retweets among the five television series. Kuzey Güney, got the lowest circulation rate with 58\% tweets and $42 \%$ retweets. These percentages provide preliminary information on television series having social capital: the more individual interaction it generates, the bigger buzz effect in online world.

Table 3- Tweet / Retweet Percentage

\begin{tabular}{lccc}
\hline Name of Series & \# of Tweets & Tweet Percentage & Retweet Percentage \\
\hline $\begin{array}{l}\text { Bir Zamanlar } \\
\text { Osmanlı-Kıyam }\end{array}$ & 15,731 & $70 \%$ & $30 \%$ \\
Seksenler & 1,527 & $78 \%$ & $22 \%$ \\
Kuzey Güney & 1,980 & $58 \%$ & $42 \%$ \\
Suskunlar & 6,235 & $64 \%$ & $36 \%$ \\
Yalan Dünya & 2,876 & $76 \%$ & $24 \%$ \\
\hline
\end{tabular}

Social capital point system is created in order to obtain a better measure of hashtag usage. This measure includes two values -tweet count and character count- to indicate an interaction with hashtag. Seksenler had the highest value with 0.53, while Kuzey Güney had the lowest with 0.43 . There is a slight correlation between tweet/retweet percentage and social capital points. Although Suskunlar came fourth with $64 \%$ in tweet percentage, it received second place with 0.50 social capital points. It also indicates that according to proportion of inclusion, social capital can change. Bir Zamanlar Osmanl1-Kiyam and Yalan Dünya had the same amount of social capital points, which shows us that even with the different volumes of tweets, the same amount of social capital could be achieved.

Table 4- Social Capital Points (SCP)

\begin{tabular}{lrcc}
\hline Name of Series & \# of Tweets & Total Character Points & SCP \\
\hline $\begin{array}{l}\text { Bir Zamanlar } \\
\text { Osmanlı-Kıyam }\end{array}$ & 11,010 & 5090.27 & 0.46 \\
Seksenler & 1,191 & 633.64 & 0.53 \\
Kuzey Güney & 1,154 & 499.69 & 0.43 \\
Suskunlar & 3,960 & 1961.25 & 0.50 \\
Yalan Dünya & 2,200 & 1003.91 & 0.46 \\
\hline
\end{tabular}


All season final episodes started to air between 08:40 pm and 09:10 pm. Depending of the airtime, the peak of circulation occurred after 1 or 2 hours later. Suskunlar showed the most different pattern among them. It reached to its peak level at 12:00am and it was the only one of the five series that made a noteworthy increase for the second time within the day. Also, while examining the fluctuation patterns of the tweets, we can observe that Kuzey Guney is singled out due to its unpredictable tweet count; the other series reach to their peaks immediately after their numbers show a significant increase while Kuzey Guney reaches peak after a noticeable drop between 9:00 pm and 10:00 pm.

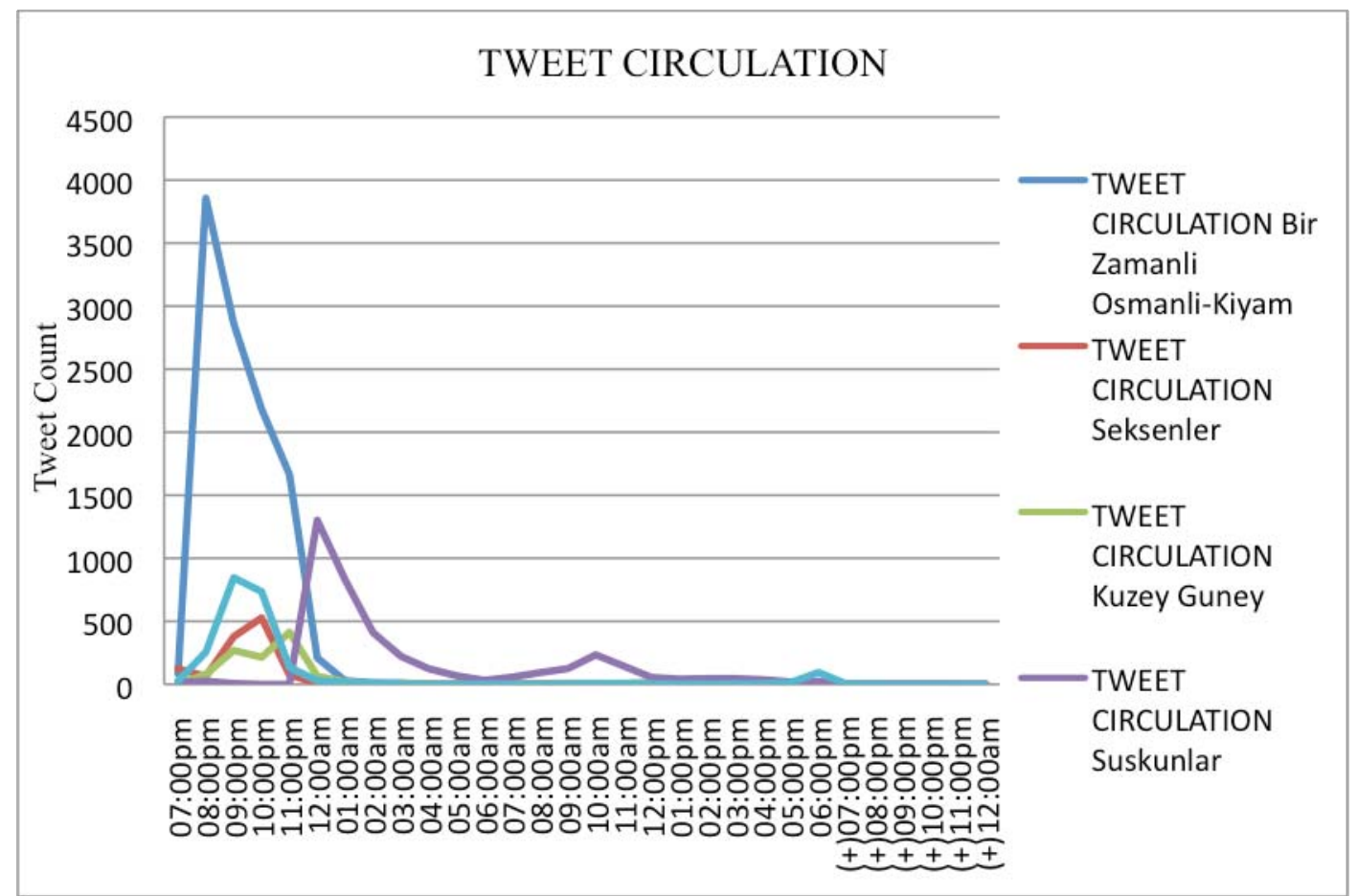

Figure 1 Tweet Circulation depending on time table

Retweets had different fluctuations patterns than tweets': they rose suddenly and showed another long and slight uptrend during the daytime due to the characteristic of the network community. When the circulation start about any subject, people have learned about it and they choose one good example among them to retweet. While all this is happening, new groups of people who keep track it also retweet in a different time period, which causes such retweet fluctuation patterns.

When we compare the two figures, we can observe that the number of retweets almost reaches the number of tweets. It indicates that when people like the tweets related to the subject matter they prefer retweeting it, rather than to create their original tweets. 


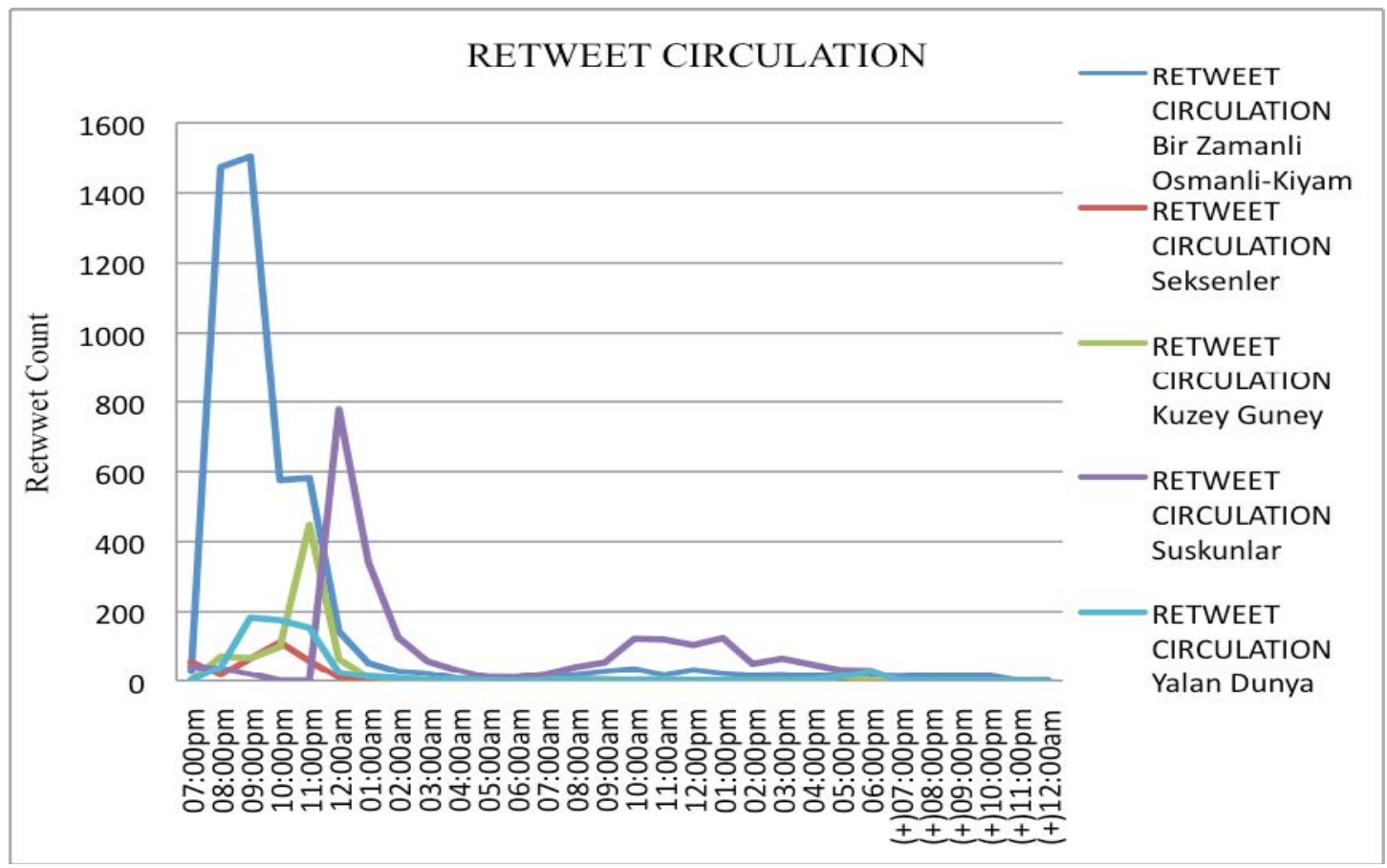

Figure 2 Retweet Circulation depending on time table

Hashtag can be only the name of television series or a specific word or a group of words that have a particular meaning within the episode. Although hashtag is used as a part of a meaningful sentence to improve interaction, sometimes it can be used by itself when it has enough meaning for the followers. Thus, more people tend to send hashtag only tweets, as opposed to repeating an existent tweet, when the hashtag is significant. Suskunlar has the highest hashtag repetition numbers, 67, with the hashtag "\#onnumarabesyildiz". Both Seksenler and Yalan Dünya came in second place in hashtag only repetition numbers with "\#seksenleriseviyorum" and "\#sevgilikazigi". There is a connection between the length of the hashtag and the number of tweets. Whenever the length of the hashtag exceeds 11 characters, number of the hashtag-only-tweets exceeds the amount of original tweets. This indicates that shorter hashtags are actually more useful in order to put together unique tweets that has distinctive meanings.

Table 5- Tweet, Retweet and Hashtag Only Repetition Numbers

\begin{tabular}{lcccc}
\hline Name of Series & HC & TRN & RTRN & HORN \\
\hline $\begin{array}{l}\text { Bir Zamanlar } \\
\text { Osmanlı-Kıyam }\end{array}$ & 11 & 17 & 512 & 9 \\
Seksenler & 20 & 3 & 58 & 57 \\
Kuzey Güney & 11 & 18 & 357 & 11 \\
Suskunlar & 18 & 15 & 511 & 67 \\
Yalan Dünya & 14 & 4 & 68 & 57
\end{tabular}

Notes: Hashtag Count (HC), Tweet Repetition Number (TRN), Retweet Repetition Number (RTRN), Hashtag Only Repetition Number (HORN) 
In social network sites, starting a circulation on any related subject needs at least one user or follower. Most of the time the user who starts this circulation does not stop there: in order to increase the volume of circulation the user utilizes its own connections. Both the television channel and the production company benefit by advertising their product with grasping the audiences' attentions. In order to accomplish this, they create user accounts in social network sites. When we analyzed the users' tweets and retweets, we could see that the most tweets and retweets were sent from user whose name was related with either the channel's or the production company's name. Kuzey Güney and Yalan Dünya, which aired in same television channel, Kanal D, got the highest tweet and retweet numbers from same accounts, which are KanalD and KanalD_fan. Same correlation could be seen in Seksenler, series that aired on TRT 1 and produced by MinT (Made in Turkey) Productions. Seksenler got the highest tweet numbers from user trttv1 and got the second highest retweet number from SeksenlerMinT.

Table 6- User, Tweet and Retweet Repetition Numbers

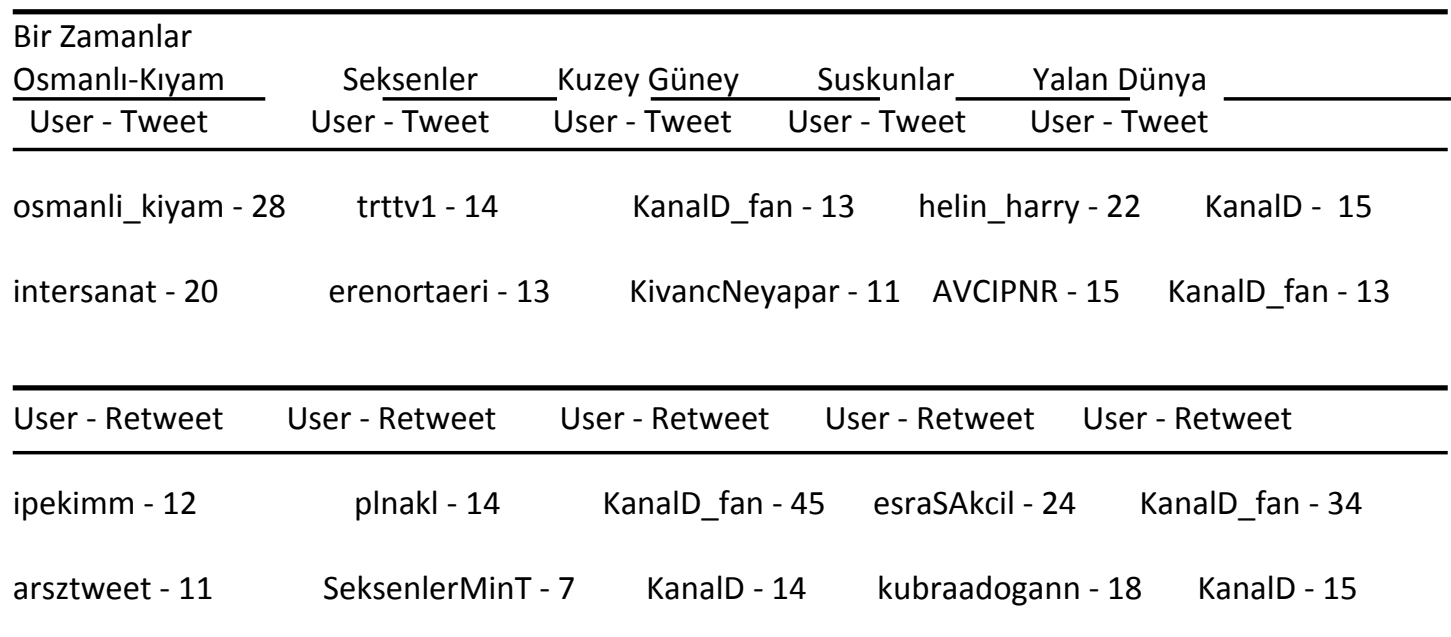

\section{Conclusions}

Social network sites are communal structures that can produce a social capital, which can also be detected in offline communities. We have observed that the 5 TV series we examined in this study have created a social capital within the network of Twitter, which provides beneficial information to their followers, simply due to the nature of social capital. These TV series utilize this social capital generated by the hashtag function as a marketing tool; Kuzey Guney of Kanal D delivers their hashtags along with the logo of a respected gsm company, Vodafone.

During the pre-study examination of the series' hashtag applications, we have observed an average of 2000 tweets per episode. However, there has been an increase on the number of tweets dramatically, particularly in Bir Zamanlar Osmanli-Kiyam with 
15,731 tweets, which leads us to believe that there was an extra pr effort to promote and expand the social capital.

Productions that traditionally reach the masses through television now make every effort to reach the online communities via social networking sites. Utilization of the hashtag application still continues through different series as well as other TV programming. This study has shown how the practice of hashtag application has proven to achieve various kinds of social capital. 


\section{References}

Bourdieu, P. (1985). The forms of capital. In J. G. Richardson (Ed.), Handbook of theory and research for the sociology of education (pp. 241-258). New York: Greenwood.

Burt, R. S. (1992). Structural holes: The social structure of competition. New York: Cambridge University Press.

Coleman, J. S. (1990). Foundations of social theory. Cambridge, MA: Harvard University Press.

DeAndrea, David C., Nicole B. Ellison, Robert LaRose, Charles Steinfield, Andrew Fiore. (2011). Serious social media: On the use of social media for improving students' adjustment to college. Internet and Higher Education 15 (pp.15-23).

Ellison, Nicole B., Charles Steinfield and Cliff Lampe. (2007). The Benefits of Facebook "Friends:" Social Capital and College Students' Use of Online Social Network Sites. Journal of Computer-Mediated Communication 12 (pp. 1143-1168). doi:10.1111/j.1083-6101.2007.00367.x

Fukuyama, Francis. (1997). The Tanner Lectures on Human Values. Delivered at Brasenose College, Oxford May 12, 14, and 15.

Habermas, Jurgen. (1984). The Theory of Communicative Action Translated by Thomas McCarthy. Beacon Press, Boston.

Kwak, Haewoon. Changhyun Lee, Hosung Park and Sue Moon. (2010). What is Twitter, a Social Network or a News Media?. World Wide Web Conference. April 26-30, 2010, Raleigh, North Carolina, USA.

Lee, C.-J., (2006). A social network approach to status aspiration: A case of South Korea. Presented at the annual meeting of the International Communication Association. Dresden, Germany.

Putnam, R. D. (2000). Bowling alone: The collapse and revival of American community. New York: Simon \& Schuster.

Rafaeli, Sheizaf and Sudweeks, Fay. (1997). Networked Interactivity. Journal of Computer-Mediated Communication, Volume 2, Number 4: March, 1997. http://jcmc.indiana.edu/vol2/issue4/rafaeli.sudweeks.html

Sakaki, Takeshi. Makoto Okazaki and Yutaka Matsuo. (2010). Earthquake Shakes Twitter Users: Real-time Event Detection by Social Sensors. World Wide Web Conference. April 26-30, 2010, Raleigh, North Carolina, USA.

Sum, Shima. Mark. R. Mathews. Mohsen Pourghasem. Ian Hughes. (2008). Internet Technology and Social Capital: How the Internet Affects Seniors' Social Capital and Wellbeing. Journal Of Computer-Mediated Communication, (pp.202-220). doi:10.1111/j.1083-6101.2008.01437.x

Television Series Rating 21-25 May 2012. SBT Rating. www.medyafaresi.com. at accessed time 26 May 2012, 2:15 pm 
Television Series Season Final Rating 04-29 June 2012. SBT Rating. www.medyafaresi.com. at accessed time 23 July 2012, 4:47 pm 